\title{
RANCANG BANGUN APLIKASI CHATTING BERBASIS WEB PADA PT SKEMANUSA CONSULTAMA TEKNIK
}

\author{
Muryadi $^{1}$, Achmad Udin Zailani ${ }^{2}$, Yudi Kurniawan ${ }^{3}$ \\ 1,2,3 Teknik Informatika, Universitas Pamulang Tangerang, Indonesia \\ Correspondence email: dosen00270@ unpam.ac.id
}

Article history: Submission date: Nov 02, 2020 Revised date: Nov 13, 2020 Accepted date: Nov 25, 2020

\begin{abstract}
Communication, discussion, and file sharing between divisions in a company is something every employee often does. The problem in this research is that not all users are connected smoothly so that it hinders communication and file transfers and in communication between divisions they have to install various applications on cellphones and PC users. This reduces the duration of time and efficiency in work. To solve this problem, a webbased chat application was designed. Because the development of these applications must use a good and structured design. Web-based chat application was created to solve this problem. This web-based application can be accessed via a web browser without having to install the application on a cellphone or laptop user. Based on the design of a web-based chat application that has been created, it is expected to be a solution for discussing, communicating and sharing files between employees in a company. In addition, it is useful to keep in touch and share files without having to install applications on cellphone or laptop users. The result of this research is that this web-based chat application can be a solution to keep communicating between employees who have difficulty accessing the internet.
\end{abstract}

Keywords: Communication, Chat Applications, Web, Internet.

\begin{abstract}
ABSTRAK
Komunikasi, berdiskusi dan berbagi file antar devisi pada sebuah perusahaan adalah hal yang sering dilakukan oleh setiap karyawan. Permasalahan pada penelitian ini adalah tidak semua user terkoneksi dengan internet secara lancar sehingga menghambat komunikasi dan transfer file dan dalam komunikasi antar divisi harus menginstal berbagai aplikasi pada ponsel dan PC user. Hal tersebut mengurangi durasi waktu dan keefisian dalam bekerja. Untuk menyelesaikan permasalahan tersebut, maka dirancang membangun aplikasi chatting berbasis web. Karena pembangunan aplikasi tersebut harus menggunakan perancangan yang baik dan terstruktur. Aplikasi chatting yang berbasis web dibuat untuk mengatasi permasalahan tersebut. Aplikasi yang berbasis web ini dapat di akses melalui web browser tanpa harus menginstal aplikasi pada ponsel atau laptop user. Berdasarkan perancangan aplikasi chatting berbasis web yang telah dibuat, diharapkan mampu menjadi solusi untuk berdiskusi, berkomunikasi dan berbagi file antar karyawan pada sebuah perusahaan. Selain itu berguna untuk tetap berkomunikasi dan berbagi file tanpa harus meng instal aplikasi pada ponsel atau laptop user. Hasil dari penelitian ini adalah aplikasi chatting berbasis web ini bisa menjadi solusi untuk tetap berkumunikasi antar karyawan yang mengalami kesulitan akses internet.
\end{abstract}

Kata Kunci: Komunikasi, Aplikasi Chatting, Web, Internet.

\section{PENDAHULUAN}

Kebutuhan paling mendasar dari manusia adalah komunikasi. Tanpa komunikasi manusia tidak akan dapat berkembang dan bersosialisasi dengan orang lain. Dari masa ke masa perkembangan alat dan teknologi komunikasi semakin berkembang pula (Yoga, 2018). Mulai dari surat, telpon, faximile, sampai yang sekarang banyak diminati adalah internet. Internet banyak diminati karena harganya yang murah dan mudah digunakan (Sutikno, Astuti, \& Khairina, 2018).

Kini teknologi chatting itu sendiri telah jauh berkembang secara pesat. Saat ini kita juga dapat melakukan chatting dengan aplikasi yang berbasis web. Hal itu akan membuat para pengembang dan programer mencoba mengembangan aplikasi chatting menjadi lebih canggih. Aplikasi chatting saat ini berkembang pesat, namun masih memerlukan proses instalasi yang rumit seiring dengan perkembangan zaman. 
Instalasi aplikasi tersebut mungkin juga terkadang dapat gagal, hal ini menjadi kurang dinamis dan praktis dalam dunia yang membutuhkan kecepatan dan keefektifan di segala bidang (Sutanto, 2011).

Untuk itu, diperlukan untuk membuat suatu aplikasi serupa namun berbasis web. Aplikasi chatting dengan basis web ini menjadi alternatif pengguna tidak ingin melakukan instalasi terhadap aplikasi chatting di ponsel atau dekstop-nya. Aplikasi ini akan dibangun menggunakan bahasa pemrograman PHP dan menggunakan MySQL sebagai servernya. PHP dipilih sebagai bahasa pemrograman karena sifatnya yang open source sehingga untuk membangun sebuah aplikasi dengan menggunakan bahasa pemrograman ini tidak membutuhkan biaya ataupun ijin yang sulit (Adinta \& Neforawati, 2017).

Untuk memberikan tampilan lebih menarik, aplikasi ini nantinya juga akan dibangun menggunakan Ajax JQuery. Aplikasi ini diharapkan dapat menciptakan suatu media komunikasi yang murah dan lebih menarik guna meningkatkan kualitas komunikasi para penggunanya (Sutanto, 2011).

PT Skemanusa Consultama Teknik (selanjutnya disebut dengan perusahaan) bergerak di bidang jasa konsultan, instalasi mekanikal dan elektrikal. Perusahaan sangat membutuhkan aplikasi chatting untuk memudahkan berkomunikasi dan berbagi file antar divisi. Perusahaan menggerakkan karyawannya dengan tipe pekerja keras dan disiplin yang sangat tinggi. Di samping itu, perusahaan juga mempunyai kontraktor untuk instalasi mekanikal dan elektrikal. Karyawan-karyawan berasal alumni-alumni perguruan tinggi terbaik di Indonesia diantaranya Institut Teknologi Bandung dan Universitas Gajah Mada. Perusahaan terbagi dari beberapa divisi yang setiap harinya melakukan interaksi kerjasama. Aktivitas komunikasi dan penyebaran informasi di perusahaan dilakukan dengan menggunakan layanan email maupun whatsapp. Layanan tersebut menggunakan perangkat yang harus selalu terkoneksi dengan internet. Apabila internet mati maka komunikasi tidak dapat dilakukan. Jalan satu-satunya untuk menyebar informasi adalah dengan menelfon atau langsung datang ke divisi yang berkepentingan, hal ini menimbulkan ketidakefisienan pekerjaan dan produktivitas menjadi terganggu. Aplikasi chatting berbasis web dapat berguna saat ini dalam komunikasinya yang digunakan untuk berdiskusi antar divisi masih manual diperlukan aplikasi chatting berbasis web. sehingga masing-masing PC user di perusahaan juga masih dapat melakukan diskusi dan komunikasi menggunakan aplikasi chatting berbasis web tersebut.
Perusahaan menghadapi beberapa masalah antara lain: (1) tidak semua user terkoneksi dengan internet secara lancar sehingga menghambat komunikasi dan transfer file. (2) untuk berdiskusi dan berbagi file dilakukan secara langsung antar divisi sehingga mengurangi keefektifan dalam bekerja dan. (3) dalam komunikasi antar divisi harus menginstal berbagai aplikasi pada ponsel dan PC user.

Ruang lingkup pembuatan aplikasi chatting, pada penelitian ini hanya dibatasi pada aplikasi yang dibangun menggunakan bahasa pemrograman PHP dan dengan MySQL untuk basis datanya. Untuk platform windows yang support: Windows XP, Windows Vista \& Windows 7 Dengan sistem minimum Windows: $2.8 \mathrm{GHz}$ Pentium 4 processor, $512 \mathrm{MB}$ of RAM atau di atasnya, 64MB of Video Card RAM, dan sudah memiliki Flash 10.x. Aplikasi berbasis web ini dapat diakses melalui komputer, laptop dan ponsel menggunakan web browser, tanpa harus menginstal pada perangkatnya serta menggunakan Ajax Jquery dengan Banwith yang kecil, sehingga data yang diperlukan untuk aplikasi ini sangat kecil.

Beberapa penelitian yang menerapkan rancang bangun aplikasi berbasis web seperti pada penelitian tentang Jquery Sebagai Komponen Usabilitas Antarmuka Aplikasi Web yang bertujuan untuk mengimplementasikan JQuery sebagai penerapan faktor kualitas usabilitas pada portal informasi Politeknik Negeri Sriwijaya. Hasil implementasi JQuery diterapkan pada portal informasi web yang memudahkan pengguna dan memberikan informasi yang lebih menarik dan atraktif (Ganiardi, Salamah, \& Kusumanto, 2015).

Rancang bangun aplikasi Chatting berbasis Web menggunakan teknologi virtual mesin yang digunakan untuk menjalankan suatu aplikasi yaitu. Docker. Implementasi teknologi ini hanya dapat dibuka jika komputer user terhubung dengan internet, Docker memudahkan dalam migrasi aplikasi ke server lainnya ketika server utama sedang down (Adinta \& Neforawati, 2017).

Rancang bangun aplikasi Chatting berbasis web yang bertujuan sebagai wadah perkenalan ataupun mencari pasangan dengan pengkategorian berdasarkan individu tertentu. Hasil pengujian sistem, user dapat melakukan global chat seluruh anggota atau user yang telah terdaftar dan dapat mengirin pesan pribadi kepada user lainnya yang diinginkan melalui link pesan pribadi (Sutikno, Astuti, \& Khairina, 2018).

Perancangan aplikasi service management pada perangkat ICT berbasis web pada unit helpdesk PT. GMF-AeroAsia untuk menangani kendala sistem, knowledge user maupun perangkatnya. Hasil pengujian sistem menggunakan bahasa pemrograman PHP dan MySql dapat memberi masukan kepada tim helpdesk untuk menangani status penanganan kerusakan yang 
dilaporkan user melaporkan email dan telepon serta dapat mengetahui histori penggunaan dan ketersediaan stock sisa sparepart (Jamaludin, Ardhiansyah, \& Zailani, 2018).

Fenomena, tinjauan pustaka dan beberapa penelitian terdahulu, melatarbelakangi untuk merancang bangun pada penelitian ini bertujuan untuk membuat aplikasi chatting berbasis web tanpa harus menginstal aplikasi tersebut pada desktop, laptop maupun ponselnya, menemukan solusi terbaik untuk tetap berkomunikasi, berdiskusi dan berbagi file antar divisi dalam satu perusahaan, khususnya pada user yang kesulitan terhubung ke internet serta memberi solusi untuk tetap berkomunikasi, berdiskusi dan berbagi file secara efisien. Rancang bangun sistem aplikasi ini diharapkan dapat memberikan gambaran umum tentang sistem yang baru atau sistem yang akan dibuat agar mudah dipahami oleh karyawan di PT Skemanusa Consultama Teknik.

Chatting adalah suatu fitur atau suatu program di Internet untuk berkomunikasi langsung sesama pengguna internet yang sedang online atau yang sedang sama-sama menggunakan internet. Komunikasi ini dapat berupa teks (text chat) ataupun suara (voice chat). Chatting tidak hanya populer di kalangan kaum remaja atau anak muda saja tetapi sudah merambah kekalangan orang tua sekalipun. Dengan adanya chatting, kita dapat dengan bebas mengobrol (Kasih \& Yasin S., 2016).

Chatting merupakan generasi dari web 2.0 yang merupakan kumpulan dari aplikasi-aplikasi seperti open-source, interactive dan user-controlled online application yang memperluas pengalaman, pengetahuan dan kekuatan pasar dari para pengguna sebagai peserta dalam proses bisnis dan sosial (Constantinides \& Fountain, 2008).

Sebuah aplikasi yang baik hendaknya memungkinkan URL (Uniform Resource Locator) dari halaman-halaman posting menjadi lebih pendek dan bersih tanpa adanya tanda Tanya (tanda?) pada link (Clean URL) sehingga dapat dengan mudah terdeteksi oleh mesin pencari (Saragih \& Husain, 2012).

Aplikasi web sekarang merupakan suatu perangkat lunak yang kompleks, menyediakan layanan-layanan yang interaktif, intensif dan customizable, dapat diakses melalui perangkat yang berbeda, dan menydiakan berlangsungnya transaksi pengguna, serta biasanya menyimpan data dalam suatu basis data (Ganiardi, Salamah, \& Kusumanto, 2015).

Konten utama halaman situs web biasanya berupa halaman situs menggunakan format HTML yang terletak di tengah halaman, dimana bagian ini sudah umum diasumsikan sebagai intisari dari halaman tersebut oleh pengguna (Sujarwadi \& Zailani, 2019).
PHP (Hypertext Preposcessor) yaitu bahasa scripting tingkat tinggi yang digunakan untuk pembuatan dan pengembangan website. PHP memiliki kelebihan penulisan skrip website yang dinamis sehingga sangat direkomendasikan untuk pembuatan website dinamis. PHP sendiri sebenarnya merupakan singkatan Hypertext Preprocessor, yang merupakan sebuah bahasa scripting tingkat tinggi yang dipasang pada dokumen HTML (Setiawan, 2017, hal. 54).

JQuery merupakan pustaka Javascript yang berisikan kumpulan kode atau fungsi program Javascript yang siap dipakai dalam pembuatan aplikasi web. Pembuatan aplikasi ini hanya memanggil fungsi-fungsi Javascript tersebut. Proses pemanggilan fungsi-fungsi inilah yang memudahkan programer aplikasi web akan lebih mudah membuat antarmuka aplikasi web yang lebih interaktif. Kode-kode program yang dihasilkan lebih ringkas dan sederhana sehingga mudah dipahami (Ganiardi, Salamah, \& Kusumanto, 2015).

Docker adalah sebuah platform open source untuk siapapun yang bertujuan membangun, mendistribusikan dan menjalankan aplikasi dimanapun seperti laptop, data center, virtual machine ataupun cloud (Adinta \& Neforawati, 2017).

Cloud computing merupakan sebuah model yang memungkinkan untuk ubiquitous (diamanapun dan kapanpun), nyaman, nn-demand akses jaringan ke sumber daya komputasi (Mell \& Grance, 2011; Waluyo, Pusparini, \& Nugroho, 2017). Lebih lanjut, komputasi awan menawarkan platform, layanan perangkat lunak dan infrastruktur yang berfokus pada pengelolaan dan koordinasi sumber daya data secara efektif untuk mencapai skala tertentu (Husain \& Budiyantara, 2020).

Proses deployment perangkat lunak salah satunya Docker juga memberikan kemudahan dan kuntungan, dimana dalam infrastructure cloud dapat menjalankan banyak pekerjaan sekaligus dengan menggunakan docker dan AWS untuk mempercepat proses deployment, optimalisasi aplikasi dan isolasi. Platform ini dapat digunakan untuk membangun, mempersiapkan, dan menjalankan aplikasi (Adinta \& Neforawati, 2017).

\section{METODE PENELITIAN}

Jenis penelitian yang digunakan pada eksperimen ini adalah eksperimen absolut mengarah kepada dampak yang dihasilkan dari eksperimen (Sugiyono, 2016). Metode penelitian menggunakan pendekatan kualitatif. Pengumpulan data dilakukan untuk menganalisis sistem informasi berjalan dengan tujuan mengidentifikasi kebutuhan pengguna. Rancang bangun sistem informasi 
chatting berbasis web ini menggunakan bahasa pemrograman PHP dan dengan MySQL untuk basis datanya, kemudian aplikasi ini didesain menggunakan Ajax Jquery dengan bandwitch yang kecil. Implementasi pada program ini menggunakan text editor notepad++, dan XAMPP sebagai web server lokalnya.

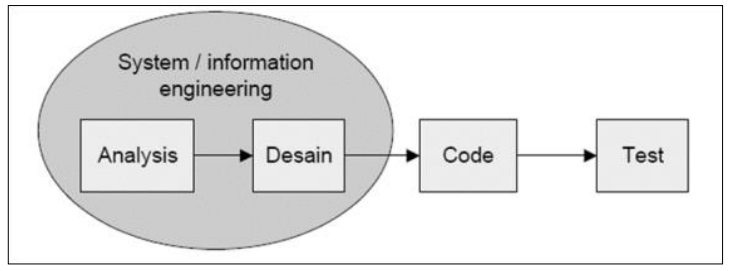

Sumber : (Rosa \& Shalahuddin, 2013)

Gambar 1. Ilustrasi Model Linear Sequential

Tahapan rancang bangun aplikasi chatting ini menggunakan model sekuensial linier melalui tahapan dari analisis, desain, pengkodean dan tahap pengujian (Rosa \& Shalahuddin, 2013; Husain T. , 2017). Alur kegiatan rancang bangun sistem ini dapat dijabarkan sebagai sebagai berikut: Analysis

Fase ini mendeskripsikan secara lengkap dan melibatkan analis sistem dan bisnis perusahaan untuk mendefinisikan baik persyaratan fungsional maupun non-fungsional (Muryono \& Budiyantara, 2018). Tahapan ini dilakukan dengan berdiskusi antar personal dengan menemui pihak yang bersangkutan, pertukaran file pun dilakukan dengan menggunakan media flashdisk. Spesifikasi kebutuhan perangkat lunak tahap ini perlu untuk didokumentasikan.

\section{Desain}

Proses yang dilakukan dengan tahapan yang cukup kompleks guna mendesain struktur data, arsitektur perangkat lunak, user interface, dan prosedur koding. Proses ini bertujuan untuk mengidentifikasikan komponen-komponen yang dibutuhkan dalam sistem informasi untuk berkomunikasi dan berdikusi maupun bertukar file.

Code

Transformasi dari tahap desain ke dalam kodifikasi (program) perangkat lunak. Hasil dari tahap ini adalah program chatting berbasis web yang dirancang yang telah dibuat pada tahap sebelumnya.

Test

Tahap pengujian dari program yang dirancang untuk membangun aplikasi chatting berbasis web, hal ini ditujukan untuk memastikan apakah sesuai dengan hasil keluaran (output) yang diinginkan dan meminimalisasi adanya kesalahan (error) Rancang bangun sistem informasi chatting berbasis web pada penelitian ini menggunakan model sekuensial linier dari berdasarkan tahap desain hingga pengujian.

\section{HASIL DAN PEMBAHASAN}

\section{Tahap Design}

Use case diagram bertujuan untuk menjalankan apa yang nantinya dilakukan oleh sistem yang berjalan meliputi mengirim dan menerima pesan, file, mengatur profil akun, memilih user untuk chatting serta mengelola file dan hak akses masing-masing user.

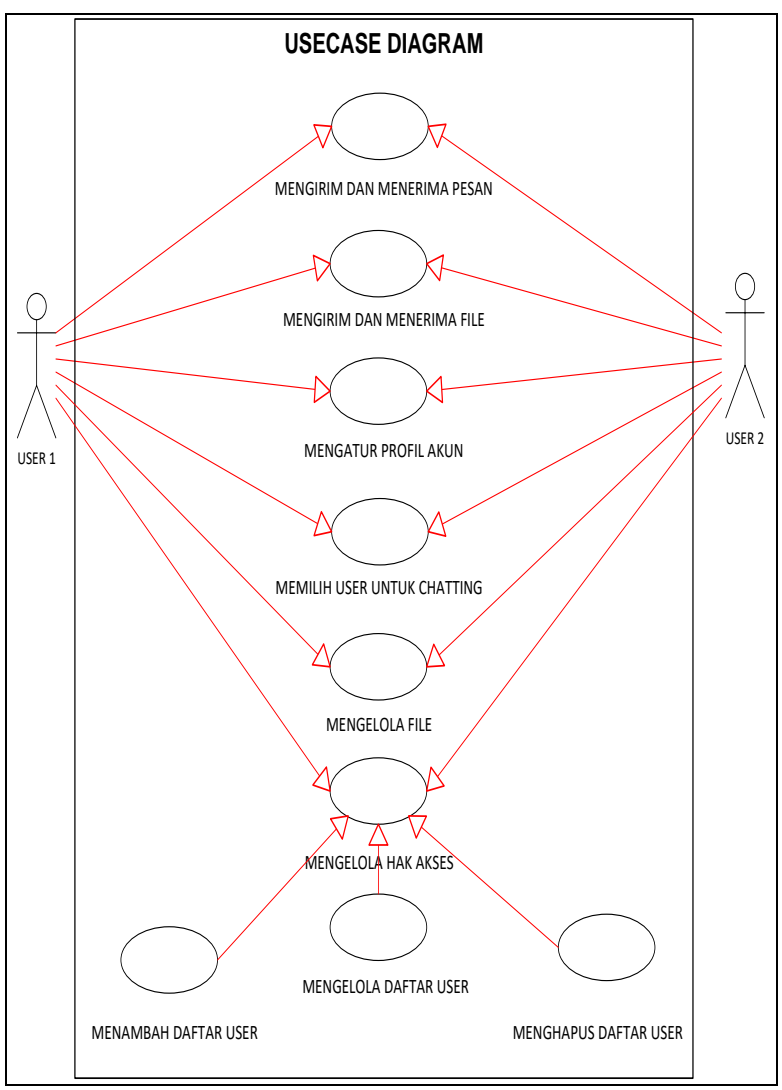

Sumber : (Muryadi et al., 2020)

Gambar 2. Usecase Diagram Mengirim Pesan

Activity diagram digunakan sebagai aliran aktifitas yang terjadi pada sistem dari login, aktifitas yang terjadi, dan logout.

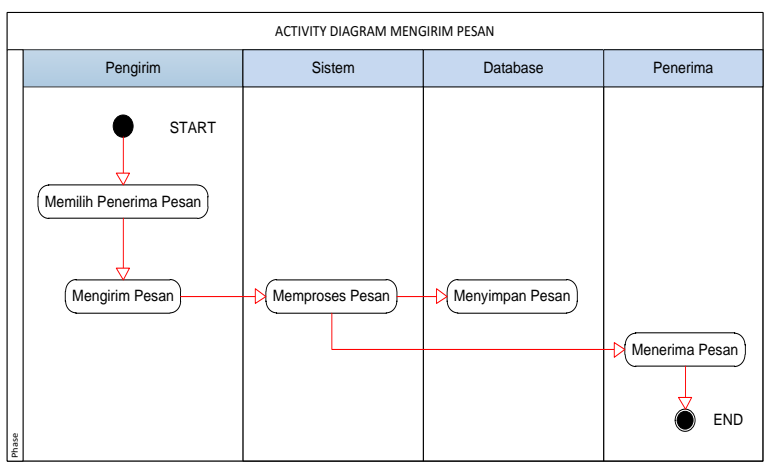

Sumber : (Muryadi et al., 2020)

Gambar 3. Activity Diagram Mengirim Pesan 


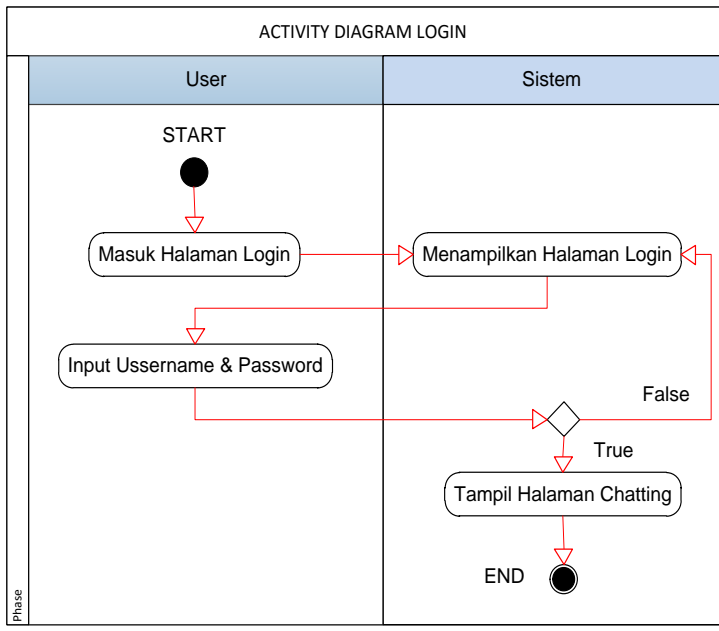

Sumber : (Muryadi et al., 2020)

Gambar 4. Activity Diagram Login

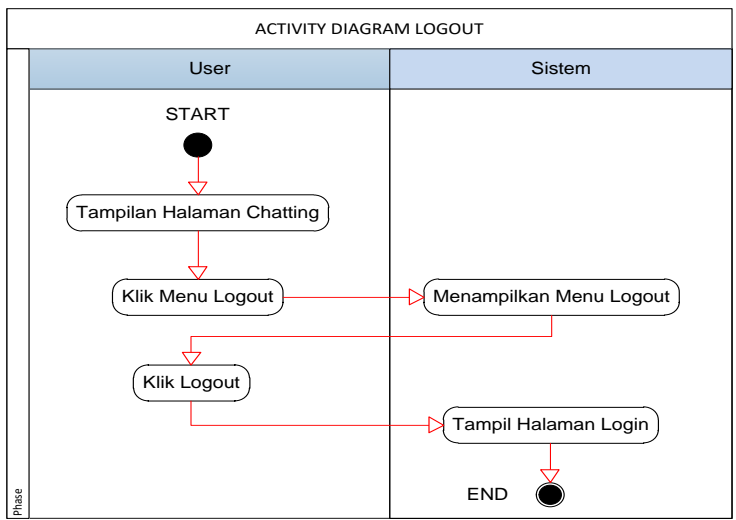

Sumber : (Muryadi et al., 2020)

Gambar 5. Activity Diagram Logout

Sequence diagram adalah digunakan untuk mengirimkan informasi atau pesan tertentu dari suatu objek ke objek yang lain.

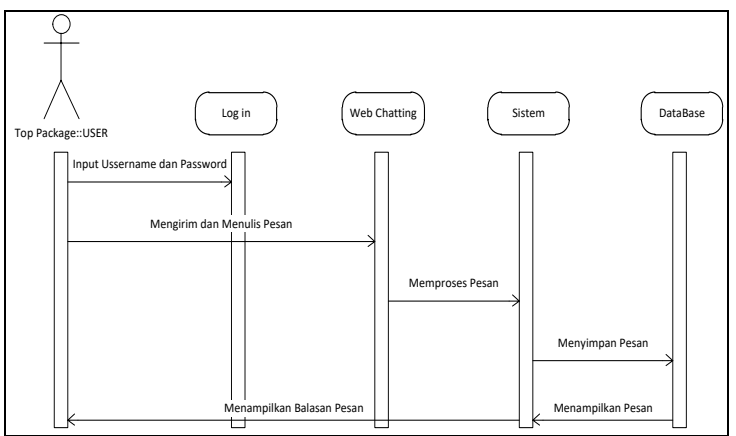

Sumber : (Muryadi et al., 2020)

Gambar 6. Sequence Diagram Mengirim Pesan

Class diagram yaitu visual dari struktur sistem program pada jenis-jenis yang di bentuk Berikut ini class diagram mengirim pesan.

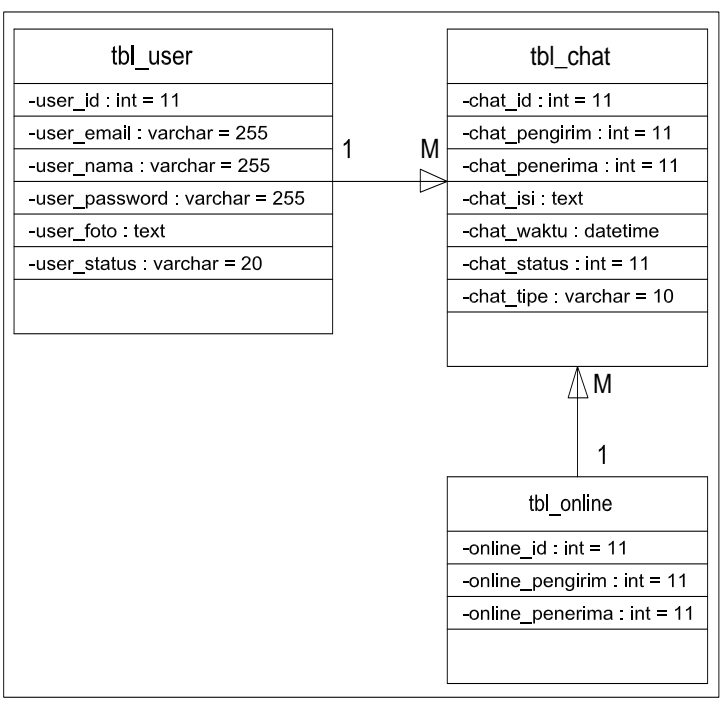

Sumber : (Muryadi et al., 2020)

Gambar 7. Class Diagram Mengirim Pesan

Setelah dilakukan tahap desain sistem, selanjutnya dilakukan perancangan basis data yang bertujuan untuk menggambarkan hubungan antar entity. Setelah transformasi Entity Relationship Diagram (ERD) ke dalam Logical Record Structured (LRS) selesai, maka dapat dibuat Logical Record Structured (LRS) dengan tabel relasi untuk membuat spesifikasi basis datanya (Tabel 1-3).

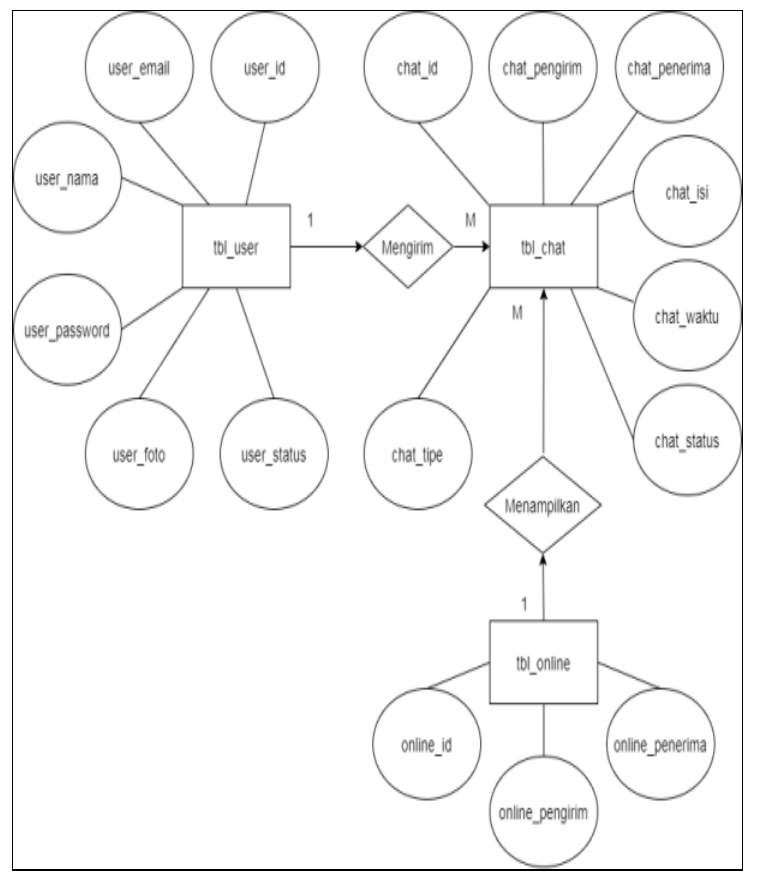

Sumber : (Muryadi et al., 2020) Gambar 8. ERD 
tabel:

Berikut ini struktur pada masing-masing

\section{Nama Tabel User}

Tabel 1. Tabel User

\begin{tabular}{|c|c|c|c|}
\hline Field & Type & Length & Keterangan \\
\hline *User_id & Int & 11 & Primary Key. \\
\hline User_email & Varchar & 255 & Email user. \\
\hline User_nama & Varchar & 255 & $\begin{array}{l}\text { Nama lengkap } \\
\text { user. }\end{array}$ \\
\hline User_password & Varchar & 255 & $\begin{array}{l}\text { Password } \\
\text { user. }\end{array}$ \\
\hline User_foto & Text & & Foto user. \\
\hline User_status & Varchar & 20 & $\begin{array}{l}\text { Status user } \\
\text { aktif dan tidak } \\
\text { aktif. }\end{array}$ \\
\hline
\end{tabular}

Sumber : (Muryadi et al., 2020)

\section{Nama Tabel Chat}

Tabel 2. Tabel Chat

\begin{tabular}{|c|c|c|c|}
\hline Field & Type & Length & Keterangan \\
\hline *Chat_id & Int & 11 & Primary Key. \\
\hline **Chat_pengi & Int & 11 & Foreign Key \\
\hline rim & & & $\begin{array}{l}\text { ke tabel user: } \\
\text { (user_id). }\end{array}$ \\
\hline **Chat_peneri & Int & 11 & Foreign Key \\
\hline ma & & & $\begin{array}{l}\text { ke tabel user: } \\
\text { (user_id). }\end{array}$ \\
\hline Chat_isi & Text & & $\begin{array}{l}\text { Menampilkan } \\
\text { isi dari chat. }\end{array}$ \\
\hline Chat_waktu & $\begin{array}{l}\text { Date } \\
\text { time }\end{array}$ & & $\begin{array}{l}\text { Menampilkan } \\
\text { waktu chat. }\end{array}$ \\
\hline Chat_status & Int & 11 & $\begin{array}{l}\text { Menampilkan } \\
\text { status terkirim } \\
\text { dan tidak } \\
\text { terkirim. }\end{array}$ \\
\hline Chat_tipe & $\begin{array}{l}\text { Varch } \\
\text { ar }\end{array}$ & 10 & $\begin{array}{l}\text { Jenis file } \\
\text { ekstensi .text, } \\
\text {.pdf, .jpg }\end{array}$ \\
\hline
\end{tabular}

\section{Nama Tabel Online}

Tabel 3. Tabel Online

\begin{tabular}{lccl}
\hline Field & Type & Length & Keterangan \\
\hline *Online_id & Int & 11 & Primary Key \\
**Online_pen & Int & 11 & Foreign Key \\
girim & & & ke tabel \\
& & & user:(user_id) \\
**Online_pen & Int & 11 & Foreign Key \\
erima & & & ke tabel \\
& & & user:(user_id) \\
\hline \multicolumn{2}{r}{ Sumber : (Muryadi et al., 2020) }
\end{tabular}

Sumber : (Muryadi et al., 2020)

\section{Rancangan user interface Login}

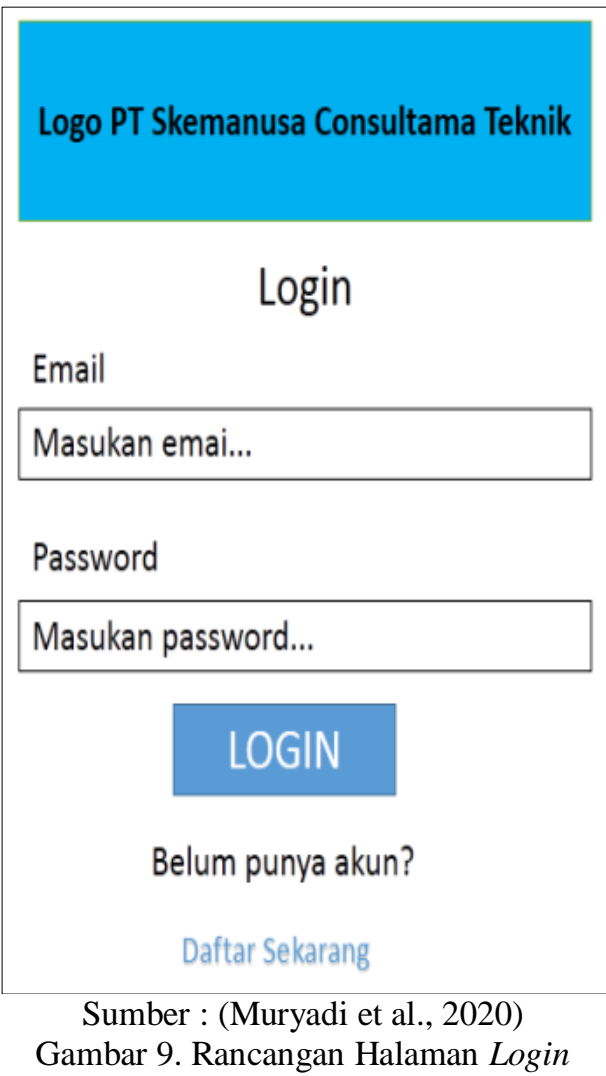

Rancangan Beranda Tambah Akun

\begin{tabular}{|l|}
\hline Logo PT Skemanusa Consultama Teknik \\
\hline \multicolumn{1}{|c|}{ Daftar } \\
Nama lengkap \\
\hline Masukan nama lengkap... \\
\hline Email \\
\hline Masukan email... \\
\hline Password \\
\hline Masukan password... \\
\hline \\
DAFTAR \\
\hline Sudah punya akun? \\
Login \\
\hline
\end{tabular}

Gambar 10. Rancangan Beranda Tambah Akun 


\section{Rancangan Dashboard Chat}

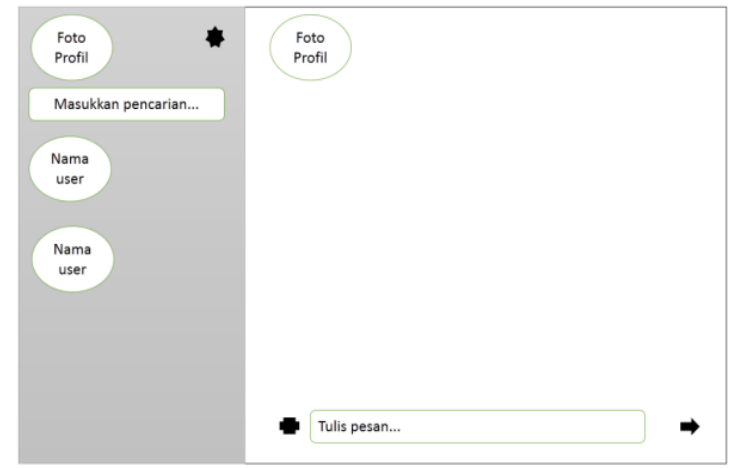

Gambar 11. Rancangan Dashboard Chat

\section{Rancangan Dashboard Edit Profil}

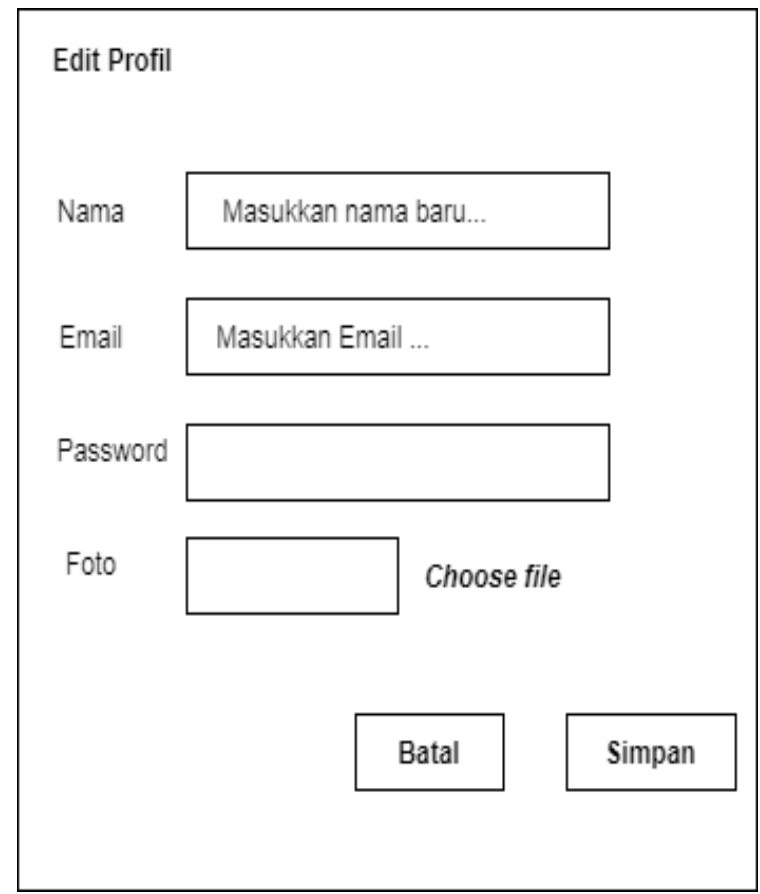

Sumber : (Muryadi et al., 2020)

Gambar 12. Rancangan Dashboard Edit Profil

\section{Tahap Implementation dan Test}

Uji coba pada aplikasi chatting berbasis web ini, diperlukan hardware antara lain: Prosesor Intel Core i3-3120 CPU @2.50 GHz, Ram 2 GB up to 16 GB, HDD: 500 GB, Monitor, Keyboard dan Mouse. Software yang dibutuhkan antara lain: Sistem Operasi Microsoft Windows 7 Pro, Database XAMPP, MySQL, Bahasa Pemrograman PHP serta Web Searching Google Chrome atau Mozilla Firefox.

\section{Tampilan Halaman Login}

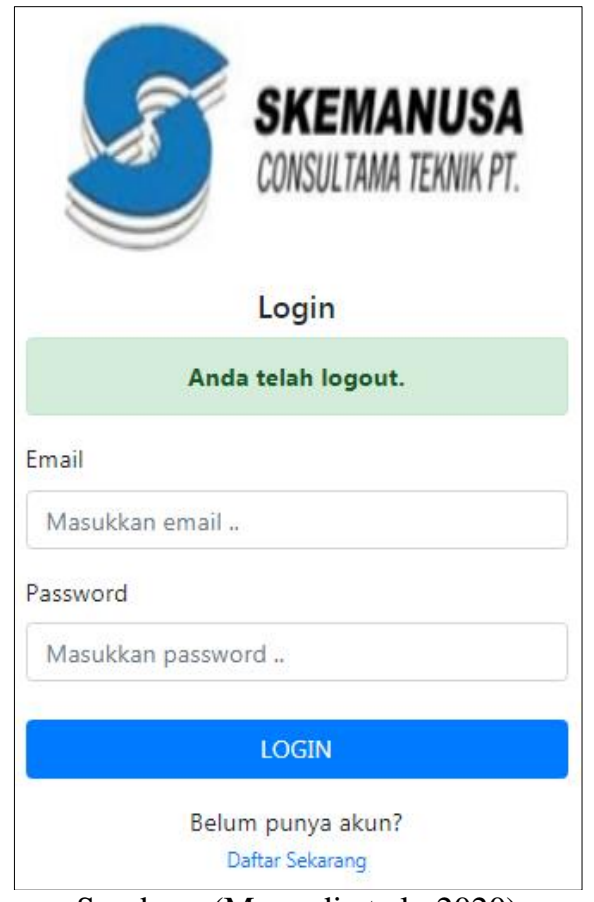

Sumber : (Muryadi et al., 2020)

Gambar 13. Tampilan Halaman Login

\section{Tampilan Halaman Tambah Akun}

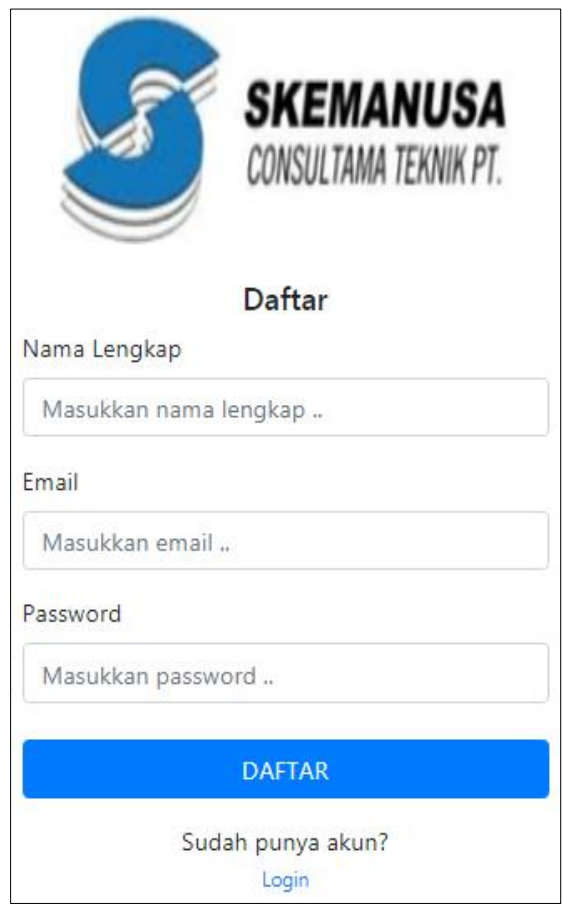

Sumber : (Muryadi et al., 2020)

Gambar 14. Tampilan Halaman Tambah Akun 


\section{Tampilan Halaman Dasboard Chatting}

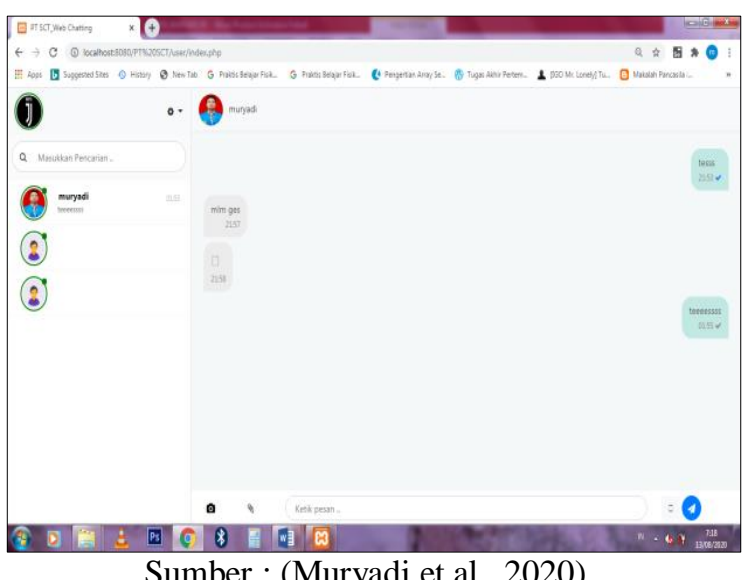

Gambar 15. Tampilan Halaman Dasboard Chatting

\section{Tampilan Halaman Edit Profil}

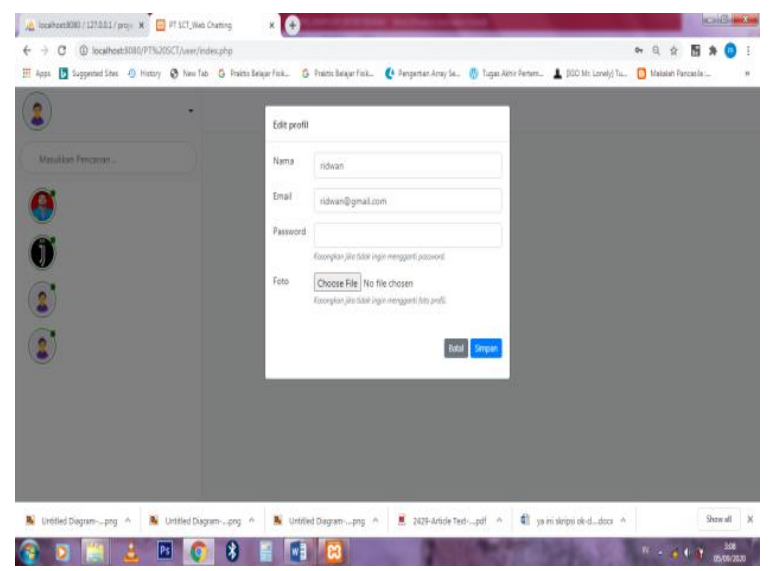

Sumber : (Muryadi et al., 2020)

Gambar 16. Tampilan Halaman Edit Profil

Hasil dari pangujian Black Box tentang kelayakan Aplikasi Chatting berbasis web menggunakan Ajax Jquery Pada PT Skemanusa Consultama Teknik yaitu:

Tabel 4. Black Box Halaman Login

\begin{tabular}{|c|c|c|c|c|}
\hline No & Tampilan & $\begin{array}{l}\text { Cara } \\
\text { Pengujian }\end{array}$ & $\begin{array}{l}\text { Halaman } \\
\text { Yang } \\
\text { Diharapkan }\end{array}$ & $\begin{array}{l}\text { Hasil } \\
\text { Pengujian }\end{array}$ \\
\hline 1. & $\begin{array}{l}\text { Halaman } \\
\text { Login }\end{array}$ & $\begin{array}{l}\text { User } \\
\text { memasukan } \\
\text { email dan } \\
\text { password }\end{array}$ & $\begin{array}{l}\text { User masuk } \\
\text { kehalaman } \\
\text { dashboard }\end{array}$ & Berhasil \\
\hline 2. & $\begin{array}{l}\text { Halaman } \\
\text { Login }\end{array}$ & $\begin{array}{l}\text { User baru } \\
\text { daftar akun }\end{array}$ & $\begin{array}{l}\text { Daftar akun } \\
\text { baru }\end{array}$ & Berhasil \\
\hline 3. & $\begin{array}{l}\text { Halaman } \\
\text { Login }\end{array}$ & $\begin{array}{l}\text { User baru } \\
\text { mencoba } \\
\text { memasukkan } \\
\text { email dan } \\
\text { password }\end{array}$ & $\begin{array}{l}\text { Masuk ke } \\
\text { halaman } \\
\text { Dasboard }\end{array}$ & $\begin{array}{l}\text { Gagal, } \\
\text { Harus } \\
\text { daftar akun }\end{array}$ \\
\hline
\end{tabular}

Tabel 5. Black Box Halaman Daftar Akun

\begin{tabular}{|c|c|c|c|c|}
\hline No & Tampilan & $\begin{array}{l}\text { Cara } \\
\text { Pengujian }\end{array}$ & $\begin{array}{l}\text { Halaman } \\
\text { Yang } \\
\text { Diharapkan }\end{array}$ & $\begin{array}{l}\text { Hasil } \\
\text { Pengujian }\end{array}$ \\
\hline 1. & $\begin{array}{l}\text { Halaman } \\
\text { Daftar } \\
\text { Akun }\end{array}$ & $\begin{array}{l}\text { User } \\
\text { memasukan } \\
\text { nama } \\
\text { lengkap, } \\
\text { email dan } \\
\text { password }\end{array}$ & $\begin{array}{l}\text { User berhasil } \\
\text { daftar akun }\end{array}$ & Berhasil \\
\hline 2. & $\begin{array}{l}\text { Halaman } \\
\text { Daftar } \\
\text { Akun }\end{array}$ & $\begin{array}{l}\text { User sudah } \\
\text { punya akun }\end{array}$ & $\begin{array}{l}\text { Masuk ke } \\
\text { halaman } \\
\text { login }\end{array}$ & Berhasil \\
\hline 3. & $\begin{array}{l}\text { Halaman } \\
\text { Login }\end{array}$ & $\begin{array}{l}\text { User yang } \\
\text { berhasil } \\
\text { daftar akun, } \\
\text { masukkanem } \\
\text { ail dan } \\
\text { password }\end{array}$ & $\begin{array}{l}\text { Masuk ke } \\
\text { halaman } \\
\text { Dasboard }\end{array}$ & Berhasil \\
\hline
\end{tabular}

Sumber : (Muryadi et al., 2020)

Tabel 6. Black Box Dasboard Chatting

\begin{tabular}{|c|c|c|c|c|}
\hline No & Tampilan & $\begin{array}{l}\text { Cara } \\
\text { Pengujian }\end{array}$ & $\begin{array}{l}\text { Halaman } \\
\text { Yang } \\
\text { Diharapkan }\end{array}$ & $\begin{array}{l}\text { Hasil } \\
\text { Pengujian }\end{array}$ \\
\hline 1. & $\begin{array}{l}\text { Halaman } \\
\text { Dasboard }\end{array}$ & $\begin{array}{l}\text { User } \\
\text { mengganti } \\
\text { foto profil. }\end{array}$ & $\begin{array}{l}\text { Dasboard } \\
\text { ganti } \\
\text { Profil }\end{array}$ & Berhasil \\
\hline 2. & $\begin{array}{l}\text { Dasbord } \\
\text { ganti profil }\end{array}$ & $\begin{array}{l}\text { Edit profil, } \\
\text { simpan profil }\end{array}$ & $\begin{array}{l}\text { Halaman } \\
\text { Dasboard }\end{array}$ & Berhasil \\
\hline 3. & $\begin{array}{l}\text { Halaman } \\
\text { Dasboard }\end{array}$ & $\begin{array}{l}\text { User baru } \\
\text { mencoba } \\
\text { mencari nama } \\
\text { user lain. }\end{array}$ & $\begin{array}{l}\text { Tampil nama } \\
\text { user. }\end{array}$ & Berhasil \\
\hline 4. & $\begin{array}{l}\text { Halaman } \\
\text { Dasboard }\end{array}$ & $\begin{array}{l}\text { User } \\
\text { mencoba } \\
\text { chatting } \\
\text { dengan user } \\
\text { lain. }\end{array}$ & $\begin{array}{l}\text { Tampilan } \\
\text { Chating }\end{array}$ & Berhasil. \\
\hline 5. & $\begin{array}{l}\text { Halaman } \\
\text { Dasboard }\end{array}$ & $\begin{array}{l}\text { User upload } \\
\text { file }\end{array}$ & $\begin{array}{l}\text { Tampil } \\
\text { upload file }\end{array}$ & Berhasil. \\
\hline 6. & $\begin{array}{l}\text { Halaman } \\
\text { Dasboard }\end{array}$ & $\begin{array}{l}\text { User melihat } \\
\text { file yg di } \\
\text { upload }\end{array}$ & $\begin{array}{l}\text { Tampil File } \\
\text { yang di } \\
\text { upload }\end{array}$ & Berhasil \\
\hline 7. & $\begin{array}{l}\text { Halaman } \\
\text { Dasboard }\end{array}$ & User logout & $\begin{array}{l}\text { Dasbord } \\
\text { login }\end{array}$ & $\begin{array}{l}\text { Berhasil } \\
\text { logout }\end{array}$ \\
\hline
\end{tabular}
Sumber : (Muryadi et al., 2020)

Tabel 7. Black Box Upload dan Download

\begin{tabular}{|c|c|c|c|c|}
\hline No & Tampilan & $\begin{array}{l}\text { Cara } \\
\text { Pengujian }\end{array}$ & $\begin{array}{l}\text { Halaman } \\
\text { Yang } \\
\text { Diharapkan }\end{array}$ & $\begin{array}{l}\text { Hasil } \\
\text { Pengujian }\end{array}$ \\
\hline 1. & $\begin{array}{l}\text { Halaman } \\
\text { Login }\end{array}$ & $\begin{array}{l}\text { User ke } 2 \\
\text { login }\end{array}$ & $\begin{array}{ll}\text { Masuk } & \text { ke } \\
\text { dasbord }\end{array}$ & Berhasil \\
\hline 2. & $\begin{array}{l}\text { Halaman } \\
\text { Dasboard }\end{array}$ & $\begin{array}{l}\text { Melihat } \\
\text { chatting user } \\
1\end{array}$ & $\begin{array}{l}\text { Tampilan } \\
\text { chatting }\end{array}$ & Berhasil \\
\hline 3. & $\begin{array}{l}\text { Halaman } \\
\text { Dasboard }\end{array}$ & $\begin{array}{l}\text { Melihat file } \\
\text { upload user } 1\end{array}$ & Tampil file & Berhasil \\
\hline 4. & $\begin{array}{l}\text { Halaman } \\
\text { Dasboard }\end{array}$ & $\begin{array}{l}\text { Download } \\
\text { file dr user } 1\end{array}$ & $\begin{array}{l}\text { Download } \\
\text { file }\end{array}$ & Berhasil. \\
\hline 5. & $\begin{array}{l}\text { Halaman } \\
\text { Dasboard }\end{array}$ & $\begin{array}{l}\text { Balas } \\
\text { chatting }\end{array}$ & $\begin{array}{l}\text { Halaman } \\
\text { chatting }\end{array}$ & Berhasil. \\
\hline 6. & $\begin{array}{l}\text { Halaman } \\
\text { Dasboard }\end{array}$ & User logout & $\begin{array}{l}\text { Dasboard } \\
\text { login }\end{array}$ & $\begin{array}{l}\text { Berhasil } \\
\text { logout }\end{array}$ \\
\hline
\end{tabular}
Sumber : (Muryadi et al., 2020) 


\section{KESIMPULAN}

Aplikasi Chatting ini bisa menjadi solusi pada masing-masing karyawan untuk tetap berkomunikasi, berdiskusi dan berbagi file antar karyawan tanpa harus menginstal sebuah aplikasi pada laptop ataupun ponselnya serta. Aplikasi Chatting berbasis web ini bisa menjadi solusi untuk tetap berkumunikasi antar karyawan yang mengalami kesulitan akses internet. Beberapa hal yang menjadi perhatian dalam penelitian ini yaitu program dari aplikasi chatting berbasis web ini, belum begitu baik hasilnya, khususnya dalam pengoperasian aplikasi tersebut. Oleh karena itu, diperlukan pengembangan dan perbaikan lebih lanjut pada masa mendatang. Aplikasi chatting berbasis web ini diharapkan dapat dimanfaatkannya sebagai sarana atau solusi untuk tetap berdiskusi dan berbagi file pada sebuah perkantoran agar tetap terjaga ke kondusifan dan keefisien dalam bekerja.

\section{DAFTAR PUSTAKA}

Adinta, F., \& Neforawati, I. (2017). Rancang Bangun Aplikasi Chatting Berbasis Web Menggunakan Docker. JOISIE (Journal of Information And Informatics Engineering), 1(1), 28-34.

Constantinides, E., \& Fountain, S. J. (2008). Web 2.0: Conceptual foundations and marketing issues. Journal of Direct, Data and Digital Marketing Practice, 9, 231-244.

Ganiardi, M. A., Salamah, I., \& Kusumanto, R. (2015). JQuery sebagai Komponen Usabilitas Antarmuka Aplikasi Web. Disprotek, 14(2).

Husain, T. (2017). Analisis Dan Perancangan Sistem Informasi Penjualan Produk Kesehatan Pada PT. ABC. ULTIMA InfoSys, $\operatorname{VIII}(2), 101-106$.

Husain, T., \& Budiyantara, A. (2020). Analysis of Control Security and Privacy Based on eLearning Users. SAR Journal, 3(2), 51-58.

Jamaludin, M., Ardhiansyah, M., \& Zailani, A. U. (2018). Perancangan Aplikasi Manajemen Service Perangkat ICT (Information and Communication Technologies) Berbasis Web. Journal ICT, 9(17).
Kasih, F., \& Yasin S., M. (2016). Perancangan Chating Room Berbasis Network. CESS (Journal Of Computer Engineering, System And Science), 1(2), 39-43.

Mell, P., \& Grance, T. (2011). The NIST Definition of Cloud Computing (Vols. Special Publication 800-145). Gaithersburg: National Institute of Standards and Technology.

Muryono, T. T., \& Budiyantara, A. (2018). Analisis dan Desain Sistem Informasi Ekspedisi Cargo Laut pada PT Artas Bangun Sari. Infotech, 4 (2), 13-18.

Rosa, A., \& Shalahuddin, M. (2013). Rekayasa Perangkat Lunak. Bandung: Informatika.

Saragih, H., \& Husain, T. (2012). Pengaruh FiturFitur Blog terhadap Continuance Intention to Visit Blogs pada Toko Online Multiply. Journal of Computer Information, 1(1), 518.

Setiawan, D. (2017). Buku Sakti Pemrograman Web :HTML, CSS, PHP, MySQL \& Javascript. (S. Adams, Ed.) Yogyakarta: STAR UP.

Sugiyono. (2016). Metode Penelitian Kombinasi (Mixed Methods). (M. Sutopo, Ed.) Bandung: CV. Alfabeta.

Sujarwadi, F., \& Zailani, A. U. (2019). Perancangan Sistem Informasi Web Scraping Resep Masakan berbasis PHP. Prosiding Seminar Nasional Informatika, 4, pp. 34-45.

Sutanto, T. W. (2011). Pembangunan Aplikasi Text Chatting dan Video Chatting Berbasis Web. Yogyakarta: Universitas Atma Jaya.

Sutikno, Astuti, I. F., \& Khairina, D. M. (2018). Membangun Aplikasi Chatting untuk Media Perkenalan Berbasis Web. Informatika Mulawarman: Jurnal Ilmiah Ilmu Komputer, 13(1), 1-6.

Waluyo, A., Pusparini, N. N., \& Nugroho, K. A. (2017). Pengembangan Asset Management System untuk Industri Building Management Berbasis Cloud. Telematika MKOM , 9(2), 67-71.

Yoga, S. (2018). Perubahan Sosial Budaya Masyarakat Indonesia dan Perkembangan Teknologi Komunikasi. Jurnal Al-Bayan, 24(1), 29-46. 
